\title{
TRANSFORMING FINANCE AND BUSINESS EDUCATION PART OF THE PROBLEM
}

FRANK M. WERNER

(corresponding author)

Gabelli School of Business

Fordham University

New York, New York, U.S.A.

fwerner@fordham.edu

JAMES A. F. STONER

Gabelli School of Business

Fordham University

New York, New York, U.S.A.

stoner@fordham.edu

Abstract. Mankind faces the challenge of transforming the existing global production/consumption/wealth-distribution system from an unjust, unsustainable one into a more just system which the Earth's resources can support. Current business education supports, enables, justifies, and intensifies the unsustainable aspects of the existing business system, and hence is "part of the problem" of global unsustainability. Although all people have opportunities to contribute to this transformation and are "called" to do so, professors in all disciplines have a special opportunity and obligation to heed such a call. This article is the first of three planned articles focusing on business education, and particularly on finance teaching within that education. It describes how business education, as currently conceived and delivered, is part of the problem and needs to be transformed. It then addresses how finance teaching, as a major contributor to business education, is in turn a "major part of the problem" and itself needs to be transformed.

Keywords: business education; finance teaching; sustainability 


\section{OVERVIEW}

The greatest temptation is to work on doing better and better what should not be done at all (Peter Drucker, quoted in Stoner, 1982: 14).

Finance professors have an exceptional opportunity to contribute to creating a more sustainable world by transforming teaching and research in their field. But while this article focuses on the opportunities for transforming teaching and research in finance, similar opportunities exist in all of the business disciplines because each of them currently teaches concepts, behaviors, and methodologies that have contributed to the unsustainable world which we presently inhabit. As such, each business discipline can make significant contributions to a more sustainable world by transforming its teaching and research.

This article is the first of three that follow the "What's so?"-_"So what?"- "Now what?" theme of this journal. It describes (1) the need to transform the dominant economic and business education paradigms that currently contribute to global unsustainability, (2) the ways current finance teaching and research are misaligned with the need for a sustainable world, and (3) how that teaching is contributing to growing national and global unsustainability problems ("What's so?").

The second article, "Transforming Finance and Business Education: Finance's Unique Opportunities," will (1) describe why finance teaching and research are in a position to make special-perhaps uniquely powerful-contributions to transforming those paradigms ("So what?"), and then (2) identify ways finance professors can change finance teaching to become part of the solution to global unsustainability, along with examples of places where such changes are already starting to occur ("Now what?"). Although all business schools can and should seek to be leaders in this transformation, that second article will note some special opportunities to contribute in this domain that are available to any faithenabled business school and especially the schools that are members of the International Association of Jesuit Business Schools.

Finally, the second article will call for readers to contribute to a third, follow-on article (working title: "Transforming Finance and Business Education: Recent Examples of Transformation"). That article will provide more examples of, and ideas for, possible successful steps to align financial management teaching and research with the requirements of a sustainable world. 
Business academics in all disciplines work long and hard to advance the contribution of their disciplines to the world. These three articles are intended to heed Peter Drucker's warning cited above. This article and the two planned follow-on articles seek to alert us to the dangers of continuing to make our contributions within the "same-old, same-old" broken disciplinary paradigms that are misaligned with the realities of the $21^{\text {st }}$ century, a century in which we must find new ways to live, work, and prosper. These articles join many others in saying we are called to think and act imaginatively and boldly to create new approaches that will begin to solve the problems of global unsustainability.

\section{WHAT'S SO?-SPECIES SEPPUKU}

\section{A Business Paradigm for Species Suicide}

A dominant paradigm for the production, consumption, and distribution of the benefits of productive enterprises has emerged. This paradigm represents a widely accepted agreement about the role of business and other productive organizations in society, the role consumption plays in the lives of consumers, acceptable (or inevitable) processes for distributing income and wealth, and the appropriate role of managers and employees in organizations. This agreed upon set of beliefs, patterns, processes, roles, and relationships can be called the dominant paradigm of business and management.

The dominant paradigm is derived from the philosophy of utilitarianism associated with Locke and others (Locke, 1690a, 1690b; Brogan, 1959; Hume, 1738; Bentham, 1776, 1789; Hutcheson, 1850; Mill, 1861). In Bentham's words, "it is the greatest happiness of the greatest number that is the measure of right and wrong" (Bentham, 1776: i). One way individuals can increase their happiness is through the acquisition of goods and services from businesses-everything from the necessities of life to luxury goods. In this philosophy, therefore, the role of the business firm is to provide the maximum amount of goods and services for consumption at the lowest possible cost, and to sell them at the best price possible to achieve the greatest profit. To do so, it must make the most efficient use of resources to produce the greatest output given its inputs, and minimize the cost of every factor of production, including labor and materials. Any revenues the firm generates beyond its costs belong to its "owners" who either started the business for the sole purpose of making money or invested in the firm and care only about the rate of return they receive on their investment. It is the role of the managers of the business to make all this happen through the activities of plan- 
ning, organizing, commanding (leading), and controlling the business' activities (Fayol, 1916, 1917, 1930).

This paradigm has achieved its greatest success in economies characterized by private ownership of productive resources. That economic system is commonly called "capitalism," although that word, like so many words ending in "ism," is open to some differences in definition and wide differences in assumed benefits (Rand, 1966; Hessen, 1979; Seldon, 2004; Nunno \& Nunno, 2010) and costs (Ollman, 1999; Klein, 2008, 2014; Schor, 2010; Ryan, 2012). But perhaps a better label than "capitalism" might be "consumerism" (Stearns, 2006; Leonard, 2011) to emphasize the theme of ever-increasing consumption driven by private enterprises that go beyond meeting human needs to generate an accelerating cycle of creating and then partially satisfying never-ending new wants. The consumerism label for the dominant business paradigm calls attention to its "take-make-waste-faster-and-faster-for-more-and-morepeople" core nature.

Whatever label is attached to the dominant business paradigm, in its idealized version unfettered private enterprises produce a just and rich world. Producers are rewarded for their contributions to the general welfare. Happiness is derived from ever-increasing consumption that is ever more widely distributed. The world is rich in resources, and negative impacts of production on the environment, consumers, workers, and communities are trivial if present at all. Markets adjust supply and demand, allocate resources, and distribute rewards to productive activities smoothly, justly, and efficiently so that any harm created by productive operations is transitory. The pricing mechanism corrects any short term anomalies. Government, to the extent it plays an active role in influencing productive operations, is an objective and accurate guardian of the common weal, uninfluenced by special interests of any kind from any source.

\section{The Dominant Business Paradigm's Deepest Assumptions}

Underlying and supporting this paradigm are a set of assumptions that have created such a deeply held view of the world that they are rarely recognized and acknowledged to be assumptions; rather, they are seen as inherent, immutable, irrefutable, and unchanging realities. Although some observers have pointed to various versions of these assumptions and challenged them on spiritual, environmental, and moral grounds, the assumptions and the world view they support are almost never seriously examined by key decision makers or by society as a whole. 
One version of these assumptions was formulated in 2005 at the Earth Values Caucus of the United Nations, and is as follows:

1. Human beings are a privileged species separate from all others in the natural world.

2. Humans are superior beings and in control of the Earth's resources.

3. Earth is merely a collection of "resources" meant for human use (and abuse).

4. Other components of the Earth have no intrinsic value and are not essential for the well-being of the planet.

5. The variety, exquisite design, and interplay of the Earth's species make no essential contribution that cannot be altered or improved by human ingenuity and technology. (Earth Values Caucus, 2005)

\section{The Paradigm's "Triumph"}

With the dismemberment of the Soviet Union as an intact "corporate body" and with the movement of Russia, China, and other countries toward greater acceptance of the dominant business paradigm, the success of the paradigm has been celebrated in many places. These celebrations have included a variety of forms and interpretations of the paradigm, including market-based liberal democracy (e.g., Fukuyama, 1992; Coyle, 2001; Reno, 2013). However, the "victory" of this paradigm has not been universally celebrated (Korten, 1995, 2010; Marks, 1997; Klein, 2008, 2014; Posner, 2009; Nixon, 2011; Sarkar, 2012).

\section{Unintended and Unwanted Consequences of the Dominant Paradigm}

Although celebrated for its success in increasing the consumption levels of many of the world's peoples, this consumerist-business paradigm has also yielded a number of problems. Two of the most serious of these problems relate to impacts on the planet's capacity to sustain the paradigm's system of production and consumption and its impact on social justice.

Simply stated, the dominant paradigm is rapidly destroying the capacity of the world's ecosystem to support the survival of our species and many others (McKibben, 1989, 2010; Thomas et al., 2004; Nixon, 2011; Klein, 2014; Adler, 2015) while it leaves over a billion people in 
severe deprivation (World Bank, n.d.; Global Poverty Project, n.d.; UNDP, 2014) and many others with lives that are far from socially and spiritually fulfilling. Producing and consuming within the parameters of this paradigm has already led to the extinction of many species (Kolbert, 2014), and continuing to do so could conceivably lead to the death of our own (Viralnova, 2014). But even if species suicide can be avoided, the uneven distribution of the paradigm's apparent benefits is yielding growing levels of income inequality and human deprivation among the world's peoples (Stiglitz, 2013; Piketty, 2014) and has been identified as an increasingly serious source of social unrest and, very likely, national and international terrorism (Schlanger, 2014; US Department of Defense, 2014). Ironically, many of the economic benefits the paradigm yields may degrade rather than improve the well-being of even those who receive the lion's share of those apparent benefits (Schor, 2010; Leonard, 2011; Dietz \& O’Neill, 2013).

\section{The Demographic Time Bomb}

Compounding these concerns is population growth. The world's population, approaching 7.2 billion as this article was written toward the end of 2014, is forecast to grow to 9.6 to 10.9 billion by 2050 (FAO, 2009; Wilson Center, 2011), and perhaps to as high as 12.3 billion in 2100 (Gerland et al., 2014). Such a population explosion would have two important ramifications for sustainability.

The majority of the global population growth is forecast to occur in the poorest countries of the world, with the population of the 49 least developed countries, primarily in south Asia and Africa, expected to double by 2050, further exacerbating existing problems of poverty and social justice (UN, 2013).

Also occurring is a shift in global income levels, some of which is already visible. According to 2005 statistics, some $1 \frac{1}{3}$ billion people had incomes above $\$ 10$ a day (Shah, 2013), enough to purchase at least moderate quantities of goods and services. Many of those above that level own houses and apartments, drive automobiles, use the latest appliances and electronics, travel for vacations, etc. With the rapid growth of the middle class in the developing world, especially in China and India, the number of such consumers might grow to roughly 3 billion by 2050. However, while increasing incomes is a positive outcome of the economic system, this growth of the middle class would place even greater demands on the Earth's resources and would be particularly problematic with regard to energy. If the demand for energy only doubles in the next $3 \frac{1}{2} 2$ decades, it would be even more difficult, if not impossible, to reverse the growth 
of carbon emissions and, with it, the damage caused by climate change and global warming. The International Energy Agency estimates that a doubling of energy use by 2050 would be consistent with a $6^{\circ} \mathrm{C}$ rise in mean global temperatures (IEA, 2014), a rise likely to be catastrophic (Lynas, 2008).

\section{The Need for a New Production-Consumption-Distribution Paradigm}

These outcomes call for drastic changes in a great many aspects of the world's production-consumption-distribution paradigm. These necessary and desirable changes include changes in what business schools teach and research, in part because current business and management education justifies and supports the continuation of the dominant paradigm. We are teaching our students how to enrich themselves by destroying the capacity of the planet to support our own and other species and to feel good about themselves as they do so.

\section{Business Training for Species Suicide}

Within the dominant business paradigm there exists a dominant business education paradigm that is consistent with the business paradigm and just as widely accepted. If the purpose of business is to provide the maximum amount of goods and services at the lowest cost and to sell them at the best price, the purpose of business education must be to prepare individuals to be successful in achieving that goal. Scholars who have studied and critiqued business education have focused much more on how effective it has been in preparing students to manage and lead within the existing paradigm-doing better and better what should not be done at all-rather than on finding ways to do what should now be done on the new planet (Lynas, 2008; McKibben, 2010) on which we must learn to produce, consume, and live.

\section{The Dominant Business Education Paradigm}

To a large extent, management education takes place within a widely accepted agreement about the role of business and other productive organizations in society, the role consumption plays in the lives of consumers, acceptable (or inevitable) patterns of income and wealth distribution, and the appropriate role of managers and employees in organizations. With few exceptions, this paradigm is accepted by business schools and guides their teaching and research (Khurana, 2007; Business-Managed Democracy, n.d). 
Around the world, curricula have been narrowed and standardized to emphasise literacy, numeracy and computer skills, and a business-friendly view of history in society. This narrowing has been firstly a means of minimising costs; cutting away extraneous subjects and learning so that schools will concentrate their efforts on teaching the "basics", that is the work-related abilities required of graduates by employers. (Business-Managed Democracy, n.d.)

Within this paradigm, business and business schools have considerable agreement on the purpose of business education and how that education should be evaluated.

\section{The Purpose of Business Education}

Management education is seen by many as an, or perhaps as "the", appropriate vehicle for training individuals to work successfully in forprofit companies in a world much like the current one. To a large extent, business and management education accepts the current state of the global business world, seeking perhaps to predict how it might evolve but devoting little energy to considering the appropriateness and possibility of substantive contributions to shaping that evolution. Even the specialized programs for such groups as public service workers (Lynn, 2006; Wilson, 2013), medical staff (Shalowitz, Nutter, \& Snarr, 1996; Parekh \& Singh, 2007; Saucedo \& Puri, 2011), and not-for-profit managers (Young, 2002) are heavily influenced by the basic for-profit paradigm taught in MBA programs. As Landsberg notes: "It has become a generally accepted truth in the nonprofit world that third-sector organizations must embrace the best practices of the for-profit, business world in order to survive" (Landsberg, 2004: Introduction). Not surprisingly, specialized programs have been encouraged to bring various aspects of for-profit management more explicitly into their teaching approaches and management practices (e.g., Salls, 2004; Childress, Elmore, \& Grossman, 2006), even if there might be some risks in doing so (Landsberg, 2004).

\section{Critiquing the Effectiveness of Business Education for the Dominant Production-Consumption-Distribution Paradigm}

A series of well-known and influential evaluations of business education has taken the accepted production-consumption-distribution paradigm as largely valid and has focused attention mostly on how effectively and/or efficiently business education prepares students and managers to contribute to existing business organizations and to move forward in their personal careers. The role of business education in supporting the existing production-consumption-distribution paradigm is not challenged in these evaluations, only how well and how 
inexpensively that education plays its role in supporting that system. For example, the three classic business education studies by Gordon \& Howell (1959), Pierson (1959), and Porter \& McKibben (1988) do not call for fundamental questioning of, let alone changes in, the ways business defines its goals and conducts its operations. They do suggest a variety of ways business education can be improved within the existing paradigm. Those suggestions have been influential in altering how business schools attempt to contribute to training individuals to be successful in that paradigm, regardless of whether or not those changes are desirable (as noted below.)

Pfeffer \& Fong (2002, 2004), Mintzberg (2004), Bennis \& O'Toole (2005), Ghoshal (2005), Khurana (2007), and other scholars have provided powerful critiques of how well, or perhaps how poorly, current business and management education does its job within the existing paradigm and how it needs to evolve to continue to do so (e.g., Thomas, Lee, Thomas, \& Wilson, 2012). But while some of those authors and others offering similar traditional critiques may hold very grave concerns about the existing for-profit-business paradigm, their critiques in what we call the traditional vein do not challenge the essence of that system. They and others have argued for ways to improve such things as the types of managers that traditional business education seeks to develop (e.g., Mintzberg, 2004), the methods for accomplishing that development (e.g., McLaughlin \& Thorpe, 1993; Kayes, 2002), the importance of transforming ethics education (Ghoshal, 2005; Gentile, 2012), and how business schools themselves need to evolve within the dominant paradigm (Thomas et al., 2012; Thomas, Lee, Thomas, \& Wilson, 2014).

Many of these critiques of current practice are quite harsh. For example, Pfeffer \& Fong reviewed research on the effectiveness of business education and business schools and concluded that the available data suggest that

\footnotetext{
... business schools are not very effective: Neither possessing an MBA degree nor grades earned in courses correlate with career success, results that question the effectiveness of schools in preparing their students. And, there is little evidence that business school research is influential on management practice, calling into question the professional relevance of management scholarship. (Pfeffer \& Fong, 2002: yy1)
}

They conclude that it would be desirable for

business schools to model themselves more closely on their other professional school counterparts and less on arts and sciences departments. 
This entails focusing research on phenomena and problems of enduring importance, and building curricula that are evaluated, in part, by how well they actually prepare students to be effective in practicing the profession. (Pfeffer \& Fong, 2002: yy2)

Unfortunately, in that article and in a follow-on piece with a very similar theme (Pfeffer \& Fong, 2004), the authors do not address the content of the "problems of enduring importance."

Sumantra Ghoshal, in his last major article before his untimely death at the much too young age of 56, built on the then current ethical and legal failures of such companies as Enron and Tyco to argue that what is taught in business schools is part of the problem of unethical and illegal business behavior. In his 2005 article, which remains the most frequently cited article published by the Academy of Management Learning $\&$ Education journal, he presents a harsh criticism of business teaching for what many call "Business as Usual." He argues that we are simply doing things we should not do to help businesses and business leaders be successful within what we call the dominant management paradigm (Ghoshal, 2005). However, he does not suggest that it is time to take action to transform the very nature and substance of that paradigm. One might be tempted to speculate what he would say now on this topic if he were still with us.

In his widely-cited critique of MBA programs in particular and management education in general, Henry Mintzberg argues for seeking to develop less calculating and distant managerial leaders and ones that more fully balance craft and insight (experience and art) (Mintzberg, 2004). However, while seeing the purpose of managing as creating, and leaving behind, stronger organizations rather than simply seeking to maximize profits or shareholder wealth, the core of Mintzberg's work does not challenge the fundamental nature of business organizations nor the production-consumption-distribution system they co-create with the rest of society.

Khurana (2007) charts the development of management education in American business schools through three phases. The first phase, which he labels "professionalization," began with the creation of business schools within the university in the latter years of the $19^{\text {th }}$ century, when wealthy industrialists sought to give back to society and garner social acceptance while providing for the future of their companies. Business education was modeled on medical and legal education, with the goal of educating managers who would run their organizations to serve the broad interests of society. The second or "managerialist" phase 
was ushered in by reports such as the 1959 Ford Foundation report that bemoaned the lack of professionalism in business education and argued for a scientific basis for business similar to that in the natural sciences. Foundation money flooded into business schools to support this transformation. Business ideals were to a large extent replaced with technical knowledge. Economics and finance became the core disciplines because of their perceived greater rigor. The third phase, "marketization," was driven by the emergence of agency theory (Jensen \& Meckling, 1976). Technical knowledge was essentially narrowed to that which increased financial value. Supported by donations from wealthy alumni and their corporations, business schools retreated from their original goal of educating professional managers to serve society to become simply producers of whatever business wanted to hire. If managers were merely agents of shareholders, there was no longer a place for ethics or ideals, only for activities that increased financial value, no matter how accomplished. Khurana concludes with a call for business schools to return to becoming agents of society and not just of shareholders.

\section{Challenging the Essence of Management Education}

Recently, a small but growing collection of critics has challenged the traditional view of how we should evaluate management education-the seeking of success within, and as defined by, the dominant for-profit business paradigm. In doing so, they are challenging what the purpose of management education should be at its most fundamental level. This challenge calls for a much bolder view of what management education should accomplish and how its success should be evaluated. Although a number of concerns are driving this bolder set of criticisms, the two concerns noted above-environmental realities and social justice issues-are receiving particular attention.

\section{Newer Criticisms of Education for Business and Management}

The traditional criticisms of business education call attention to shortcomings in training individuals to achieve success in the dominant traditional for-profit business paradigm-succeeding at "Business as Usual (BAU)." These shortcomings include the lack of ethical behavior during the pursuit of that success and perhaps insufficient attention to contributing to social and maybe even environmental needs-that is, failure to contribute to "Corporate Social Responsibility." However, these traditional criticisms accept and perhaps embrace the appropriateness of the dominant business/economic paradigm, or perhaps they simply succumb to the generally agreed inevitability of that paradigm's continued dominance. 
More recent criticisms identify the need for moderate changes within the context of the dominant paradigm and call for initiatives to reduce or even overcome the impacts of climate change in particular and global unsustainability in general. While accepting the basic form of the dominant paradigm, they may also call for a greater focus on some aspects of social injustice. This perspective calls for some moderate changes in current business practices and structures but seems to be optimistic that a sustainable world can be achieved with the basic economic and business paradigm essentially intact. In this perspective, individuals are to be trained to succeed at "Amended Business as Usual (ABAU)." In doing so, individuals and businesses will benefit because many of the desired changes offer excellent opportunities to increase business profits-a comfortable "win-win" situation not requiring the rigors and risks of deep or transformative change.

\section{The Need to Transform the Dominant Business Education Paradigm}

A more encompassing criticism calls for fundamental transformation of the dominant business paradigm (Spitzeck \& Pirson, 2009; Korten, 2010; McKibben, 2010; Schor, 2010; Sarkar, 2012; Eversole, Korten, \& Speth, 2014; Klein, 2014; Adler, 2015) and the creation of business education consistent with creating and working within a new, globally sustainable business paradigm (e.g., Stead \& Stead, 2009; Wankel \& Stoner, 2009; Starik, Rands, Marcus, \& Clark, 2010; Amann, Pirson, Dierksmeier, Von Kimakowitz, \& Spitzeck, 2011). In this perspective, individuals are to be trained to contribute to transforming the basic production-consumption-distribution business paradigm into one that will contribute to, and ultimately create, a sustainable world, and to work within that transformed paradigm when the transformation has occurred, that is, in a world of "Not Business as Usual (NBAU)," or perhaps BSW-"Business for a Sustainable World," or BGF_-"Business for Global Flourishing."

\section{The Need to Transform Finance Teaching}

Finance teaching has been focused on training individuals to succeed at Business as Usual (BAU). In some schools, finance professors are researching and starting to teach their students to discover opportunities to contribute and to succeed in Amended Business as Usual (ABAU)to improve corporate profits while doing less environmental harm and perhaps even less social harm. ${ }^{1}$ These contributions are valuable both for

${ }^{1}$ Examples are Bruce Usher at Columbia University who teaches a course entitled "Finance \& Sustainability," Carlos Alberto Vargas at Harvard University who teaches a course entitled "Sustainable Finance and Investments," Gautam Kaul at 
potential reductions in the damage to the world and its peoples which they might achieve and for the learning opportunities which they offerlearning how to bring into being ways of producing and consuming that contribute toward achieving a less unsustainable world, and learning about the difficulties of doing so. However, the finance field's intellectually more challenging and greater contributions exist in discovering the role finance can play in contributing to the necessary and desirable transformation of business and management education so that it will be consistent with the need for a sustainable world-creating the world of Not Business as Usual (NBAU).

\section{Finance Teaching for Species Suicide}

The way we currently teach finance and the roles we advocate for our students in the business world are in many ways inconsistent with a socially just and sustainable world in which our own and other species can "flourish" now and in the future (Ehrenfeld \& Hoffman, 2013). They are also often inconsistent with many organizations' stated missions, even when those missions are centered around financial wealth maximization. In this section, we examine (1) the present ways of teaching finance, (2) the assumptions on which finance teaching is based, (3) the goals for business practice specified by finance teaching, and (4) the roles finance teaching encourages business students to play in their subsequent careers.

\section{Present Ways of Teaching Finance}

There appears to be considerable agreement among finance faculty worldwide about what constitutes the subject of finance and how it should be taught. Except for minor variations that come from professors' personalities and preferences, finance syllabi hardly differ from university to university. Today, although there are many finance textbooks available, the vast majority of finance courses use one of only a very few of those textbooks ${ }^{2}$ and cover the same topics in essentially the same

the University of Michigan who teaches a course entitled "Sustainable Finance," and Frank Werner at Fordham University who teaches a course entitled "Sustainability and Finance." Other example courses are "Finance and Valuing Sustainability" at Babson College and "Finance II: Corporate Finance and Sustainable Capital Management" at Marlboro College.

${ }^{2}$ Of the estimated 100,000 introductory finance textbooks sold every year, nearly $40 \%$ were written by Eugene Brigham (http://fortune.com/2011/06/23/the-story-behind$a-b$-school-textbook-fortune/). In Amazon.com's list of the 100 best-selling books on its website in the category of "Books > Textbooks > Business \& Finance > Finance" (http:// www.amazon.com/gp/bestsellers/books/491594/ref=pd_zg_hrsr_b_2_4_last\#1), 
way. This uniformity is particularly present within schools where the faculty agrees on a common textbook and common coverage.

Our recent early survey research of finance department chairs suggests a lack of knowledge among finance faculty about the connection between global sustainability and academic finance (Werner \& Stoner, 2014). ${ }^{3}$ One consequence of this situation is that it is rare to find a finance course in a top-ranked business school or a session in a major academic conference in which finance faculty criticize the core concepts of their discipline. ${ }^{4}$ We find this lack of open-minded inquiry into the underpinnings of the field quite disturbing, and not dissimilar to the position of the Catholic Church in the $14^{\text {th }}$ century when Nicolaus Copernicus disputed the Church's belief that that the earth was the center of the universe. The Church saw Copernicus's model as a threat to its broader goals even though the prevailing geocentric model was mostly irrelevant to religious belief and faith, and even as evidence of the inadequacy of the geocentric model continued to accumulate. In the same way, we sense that many finance faculty see the questioning of finance orthodoxy as a threat to the discipline when, in fact, we suggest that it is much more likely the lifeblood upon which the discipline can grow and flourish.

Even those colleagues who accept that there are deficiencies in current finance models tend not to question them with their students.

fifteen are books used in introductory finance courses. Of the fifteen, six are by Brigham (with co-authors Michael Ehrhardt and Joel Houston), four are by Stephen Ross (with co-authors Randolph Westerfield and Bradford Jordan), two are by Lawrence Gitman (with co-author Chad Zutter), two are by Stanley Block (with co-authors Geoffrey Hirt and Bartley Danielsen), and one is by Robert Parrino (with co-authors David Kidwell and Thomas Bates). The emergence of a few dominant textbooks is also a result of the consolidation of the textbook publishing industry. Whereas there were over a dozen major publishers of finance textbooks as recently as 20 years ago, today there are only four (listed in order of size and market share): Pearson, Cengage Learning, McGraw-Hill, and Wiley (http://kindlesforkids.wordpress.com/2008/09/15/ny-timessays-textbook-publishers-are-like-drug-companies-prozac-with-your-proust/).

${ }^{3}$ In response to the question "Are any of your colleagues in your school's finance faculty, including you, doing research and/or teaching about the possible impact of climate change and global unsustainability on the theory or practice of finance?", 55\% of the respondents answered no and $28 \%$ answered "I don't know of any." Only three respondents answered yes, including the chair at Fordham University, referring to one of the authors of this article.

${ }^{4}$ The authors have proposed sessions on desired and emerging changes for finance teaching, research, and practice to be consistent with global sustainability for each of the past seven annual meetings of the Financial Management Association, all of which have been accepted for the program. The most recent meeting in 2014 was typical of our experience: of the 310 sessions listed in the program, ours was the only one that addressed the subject of substantial change in orthodox finance. 
When we ask our more sympathetic colleagues why they do not spend class time questioning the foundations of finance thought, we are told that they are constrained by their standardized syllabus, or that there is simply too much material to cover in the introductory course, leaving little room for innovation, or that they feel they must devote their limited class time to topics that will train their students for their first internship or job.

With so few finance faculty actively discussing and questioning the basics of finance, there is a lack of peer support to innovate. Many colleagues are simply not interested. Junior faculty look at their senior colleagues and become concerned that innovation may equate to professional suicide since promotion and tenure often depend on publishing in top-ranked journals. Their senior faculty and the editors of those journals, effectively the gatekeepers for promotion and tenure, tend to be those who developed the current orthodoxy. Faculty of all ranks observe that chairs, journal editorships, and lucrative consulting opportunities are more likely to go to orthodox leaders than to rebels. Besides, it can be frightening and perhaps even threatening to be different, and not accepting the beliefs of others may be interpreted as a lack of professional competence.

\section{Assumptions on Which Finance Teaching is Based}

In their 1959 Ford Foundation report, Robert Gordon and James Howell criticized business school education for not being sufficiently rigorous. They observed that many faculty had entered the academy after careers in business and tended to teach from their experience, however narrow that might have been. Gordon and Howell urged business professors to depend less on personal experience and instead to research and develop-and eventually teach — a body of knowledge with a strong theoretical base (Gordon \& Howell, 1959). In no business discipline was this recommendation adopted more wholeheartedly than in finance. Taking advantage of the newly emerging computing power of the day, finance faculty dove headlong into numerical research, often creating models of economic behavior based upon similar models in the physical world. Since there are no "laws of finance" as there are laws of nature, the models were based on the beliefs of the day about people, about organizations, and about society, and an entire body of literature was developed that still shapes the discipline of finance to this day.

Many of the initial assumptions underlying financial models have, so far, withstood the test of time. However, several of finance's fundamental assumptions may no longer be true-if they ever were-and stand out 
for us as leading to inconsistencies with both the broad social mission of business and the stated missions of specific companies.

Meeting "consumer demands." A common assumption is that businesses should produce and deliver whatever people are willing to pay for, regardless of any impact on the consumer, the environment, or on society. Or, perhaps to make that statement a bit more realistic, it might be amended to include: "to pay for whatever businesses' investments in persuasive marketing programs can convince people to pay for." If consumers demand (or can be convinced to "demand") large, energy-inefficient houses, we should construct them. If drivers demand gas-guzzling SUVs, we should build them. If street gangs demand machine guns, we should make them. If college students and others demand narcotic drugs for supposedly "medicinal" but more likely recreational purposes, we should develop and produce them. All that matters according to current finance theory is that the firm makes money since, as finance defines it, that means that both parties to the transaction are "better off." By teaching that the consumer is always right, and by ignoring how consumers come to be "always right" in their choices, we disconnect finance from any ethical, environmental, or social consciousness.

Rational economic man. A second popular assumption is that of "rational economic man," that people always act rationally when engaging in business transactions and that irrationality and emotionality are rare and unimportant exceptions to the rule. From the late 1960s until the late 1980s, this assumption was so fundamental to finance that virtually no contrary research was published. Beginning in the late 1980s, nonrational finance behavior began to be categorized and published under the heading "behavioral finance," yet it continues to be treated as a list of exceptions rather than as a challenge to the assumption of rational behavior. By assuming rationality, we simplify the mathematics of finance models but fail to capture a large part of the behavior of economic actors. The supporting assumption that this rational person is fully and accurately informed frequently nestles comfortably and unexamined within this larger assumption.

Efficient markets. A third popular assumption is that financial markets are efficient in the sense that they promptly impound all public information into security prices. If so, they give accurate signals to business on a minute-by-minute basis, guiding managerial choices. But while studies of major securities markets have generally found a high degree of semi-strong efficiency, some researchers have found contrary results (Rosenberg, Reid, \& Lanstein, 1985; Lehmann, 1990), and smaller markets and markets for less liquid assets are less likely to be efficient. In addition, increasing numbers of trades on the major exchanges are 
being executed automatically by computers using trading algorithms that are not based on fundamental economic value, and with the emergence of high-frequency trading, the average share of stock on the major exchanges is changing hands at an ever greater rate. This rapid trading of company shares suggests that in many cases, the "corporate shareholders" in whose names companies claim to be maximizing value are often fictional. The suggestion that the so-called corporate shareholder is a pure fiction is made very strongly by Lynn Stout (2012) in her book The Shareholder Value Myth.

Fair and appropriate ground-rules. A fourth assumption is that governments and the markets will always set the correct ground rules for society. If true, there are at least two implications for finance decision-making. One is that company decision-making occurs in a context where governments and the markets assure that externalities are properly priced. If the least expensive way to dispose of waste is to dump it into a nearby lake, polluting the lake can be considered the most socially acceptable and socially efficient waste disposal process. The second implication is that the law defines not only what is legally acceptable but also what is socially acceptable. By this logic, if there is a law explicitly prohibiting pollution, it should not be done; however, in the absence of such a law, polluting activities that increase the value of the company are not only good business practice-they are what society desires. What matters is adherence to the letter of the law, not the spirit of the law, and surely not going beyond the dictates of the law. In finance, many of these activities are celebrated under the heading "financial engineering," and we teach that they are good business practice, regardless of their impact on the environment and society.

Perhaps the most impactful expression of this belief was in the words of the renowned economist Milton Friedman who, in arguing for the validity of this assumption, wrote: "There is one and only one social responsibility of business - to use its resources and engage in activities designed to increase its profits so long as it stays within the rules of the game, which is to say, engages in open and free competition without deception or fraud" (Friedman, 1970). This perspective ignores the possibility that governments might be perpetually playing catch-up since businesses are far more nimble and creative than governments in discovering opportunities at the edge of legality. It also assumes that businesses will not have a disproportionate impact on legislators and therefore on government policy. Frankly, it has long been difficult for many observers to understand how Professor Friedman could seem to have assumed so blandly that government can be counted upon to be an objective determiner and protector of the rights and best interests of the citizen population, and to have paid so very little attention to the 
obvious incentives and repeated successes of business organizations in tilting the legal playing field in favor of their own financial interests.

\section{Assumptions and Actions in the "Real World"}

These assumptions and others like them have guided theorists and practitioners as they contributed to the development of finance. Nevertheless, as we have suggested, they may no longer be true-if they ever were. The financial crisis of 2007-2008 and its continuing aftermaths provide excellent illustrations of how much actual behavior might deviate from the behavior that would be predicted by many of these assumptions.

- $\quad$ Finance assumes that business should produce and deliver whatever people are willing to pay for, yet many people were sold houses they could not afford, and builders constructed homes on speculation. Both sets of parties were convinced that house prices would continue to rise-seemingly forever.

- $\quad$ Finance assumes that economic actors are rational, yet finance professionals invested in complex securities and engaged in complex transactions of which even they had very little understanding.

- $\quad$ Finance assumes that fully efficient markets give accurate signals to business, yet the markets did not accurately price the risk of many assets.

- $\quad$ Finance assumes that governments will set the correct ground rules for society, yet quite a few laws passed and regulations issued in the U.S. in the decade leading up to the crisis were detrimental to the country's financial health. The Financial Services Modernization Act of 1999 led banks to make risky investments with the savings and checking deposits of their retail customers. The Commodities Futures Modernization Act of 2000 prevented regulation of the derivatives market. In 2004, at the urging of investment banks and based on those banks' own risk assessments, the SEC lowered bank capital requirements, increasing banks' financial risk. Bank mergers were permitted, even encouraged, leading to large banks that were similar in character to public utilities but with limited regulation. These banks could take excessive risks due 
to explicit and implicit federal guarantees that could be counted on because they had become "too big to fail."

- $\quad$ Finance accepts Milton Friedman's statement that the only social responsibility of business is to increase its profits without deception or fraud, yet in the pursuit of profits, many large businesses contributed to the crisis. Banks made mortgage loans to homebuyers who were obviously unable to repay them in order to collect the origination fees, often lending more than the value of the real estate. Companies pursued "off-balance sheet financing" to keep debt and assets, some "toxic," off their balance sheets, hiding them from investors so they would value the company's stock more highly. Financial firms saw deal-making as more important than the substance of the deal, and by 2007 the total value of outstanding OTC contracts in the world derivatives market was more than ten times global GDP. ${ }^{5}$ Credit rating agencies, paid by those they were evaluating, overrated complex securities which permitted pension funds to invest in high-risk assets that were quite inappropriate for their clientele and, had they been correctly rated, might have been prohibited by law or by the fund's charter.

\section{Goals for Business Practice Specified by Finance Teaching}

Finance theory specifies a single goal for all for-profit businesses: to maximize the wealth of the "owners" of the company. Since the corporation has been the dominant form of business organization (by sales) in the United States where the theory was most fully developed, the goal is typically stated as "Shareholder Wealth Maximization (SWM)."

In its strictest form, SWM argues that every input to the firm is a cost to be minimized. So, for example, employees are merely a cost of doing business, and their salaries and benefits should be minimized lest value be taken from the shareholders. Natural resources should be consumed at the lowest cost in pursuit of SWM regardless of waste produced or environmental degradation caused; resource depletion is not a concern because market prices can be assumed to adjust to solve any

${ }^{5}$ The Bank for International Settlements reported that the total notional value of over-the-counter derivatives at the end of 2007 was US \$596 trillion ("OTC derivatives market activity in the second half of 2007," Bank for International Settlements, May 2008: 1.) According to the World Bank, global GDP in 2007 totaled US $\$ 55.4$ trillion (http://data.worldbank.org/indicator/NY.GDP.MKTP.CD?page=1). 
potential problems. A less strict approach to SWM accepts that actions such as some increase in employee compensation and some concern for resource use might translate into greater productivity and hence greater profitability; but, of course, any such actions should only be taken if they increase shareholder wealth. As such, environmental and social goals do not feature in SWM; determining and achieving them are simply not the role of business.

We put the word "owners" within quotation marks to highlight that the SWM goal itself is based on still another assumption-that a corporation's shareholders are its "owners," residual claimants who bear all the risk of corporate activities. However, some legal scholars have now concluded that this is an impossibility under U.S. law. In the United States, the $14^{\text {th }}$ Amendment to the Constitution has been interpreted to make a corporation the equivalent of a person in the eyes of the law, and since the abolition of slavery in 1863 it has been illegal for one or more persons to "own" another. Furthermore, the legal status of shareholders as residual claimants holds only in bankruptcy. For a going concern, shareholders are no different from other stakeholders who invest time, money, or other resources in exchange for a fair return and, in doing so, bear a portion of the risks inherent in the corporation's operations and financing (Stout, 2012).

\section{Career Roles Advocated by Finance Teaching}

Since we teach that the goal of the firm is SWM, we are effectively instructing our students that they should treat everyone and everything as a means to the sole end of enriching these so-called shareholders. Customers, employees, bosses, subordinates, communities, other species, the atmosphere, watersheds, rain forests, coral reefs, historical and cultural sites, etc. have no inherent value and only whatever rights are protected by enforced laws. Either explicitly or implicitly, we teach that doing anything else-such as pursuing environmental or social goalsis a recipe for disaster: the business will lose out to competitors who exclusively pursue financial goals, or the business will be taken over by new managers who will enrich themselves and shareholders by pursuing SWM.

\section{LOOKING AHEAD: "SO WHAT?" AND "NOW WHAT?"}

As noted earlier, the second and third planned articles in this series will address the "so what?" and "now what?" questions, questions such as the ones asked by a reviewer of this article: 
... (f)inance education is problematic, given its unrealistic assumptions, but what should replace it? What better assumptions can we make? Do we incorporate more tools for valuing a company, like stakeholder valuations and social cost indicators, outside the current primacy of the stock price? Do we change the way we account for negative external effects like pollution, unemployment, or wastage?

The second article will call for a new approach to teaching and researching finance that is bold and creative, an approach that might be called "Samurai Finance." Samurai Finance would be fully committed to creating new kinds of businesses and other productive organizations that meet human needs in ways that would allow our own and other species, in the words of John Ehrenfeld (2008), "to flourish forever." The second article will suggest why, at this time, the field of finance has an almost unique opportunity to contribute to a more sustainable worldan opportunity similar to the one Richard Nixon had when he visited China to improve U.S.-Chinese relations.

To explore where Samurai Finance might be starting to happen, the second article will describe ways to align finance teaching with the realities of today's and tomorrow's worlds. One step in making Samurai Finance happen would involve examining the basic assumptions of finance teaching and following the path suggested by more realistic assumptions about economic actors and markets. The article will explore finance's teaching and research opportunities to contribute to a more sustainable world by using the frameworks suggested in this article: the world of business as usual, the world of amended business as usual, and the world of not business as usual. Exploring these opportunities will also call attention to the ideological barriers to fresh thinking in finance.

The second article will also address the contributions to developing finance teaching and research consistent with a sustainable world that are starting to emerge in academic institutions, for-profit businesses, and other organizations. Among the academic and related institutions and initiatives that can contribute, and to some extent are already contributing, to the evolution of finance teaching and research are the Aspen Institute, schools and programs whose focus is sustainability, schools with sustainability degrees, schools with sustainability majors and minors, and sustainability-focused finance courses. Others that are also potential contributors to this transformation in finance teaching and research include: the B-corporation initiative; the inspiring work of Ray Anderson and his company Interface; Bloomberg, LP; the U.S. military; the Capital Institute; the not-for-profit community; the Humanistic Management Network; and the Center for Business as an Agent of World Benefit. 
The second article will also suggest that this call for the transformation of finance teaching offers exceptional opportunities for business schools in faith-enabled universities since the commitment to global sustainability is very consistent with the mission of these schools. Support for faith-enabled business schools to take leadership in transforming finance teaching and research is offered by their universities' missions, the American College and University Presidents' Climate Commitment, and the Principles for Responsible Management Education.

Among faith-enabled business schools there is a very special opportunity for Jesuit business schools. This opportunity arises in part from the large number and excellent reputations of Jesuit business schools around the world. Jesuit universities have been called very clearly to commit to global sustainability by the three most recent popes, The Jesuit Task Force Report on Ecology "Healing a Broken World" (Social Justice Secretariat at the General Curia of the Society of Jesus, 2011), the 2014 high-level Vatican conference "Sustainable Humanity, Sustainable Nature: Our Responsibility," and a series of other conferences and meetings such as the 2015 Loyola University of Chicago Second Conference on Climate Change. One example of how these calls are influencing Jesuit business schools is suggested by the action taken by the International Association of Jesuit Business Schools. Responding to a resolution passed at the 2009 IAJBS World Forum at XLRI in Jamshedpur, India, the IAJBS board committed to devote the IAJBS World Forums for the subsequent ten years to the theme of leadership for global sustainability-a commitment that led, among other things, to the proposal at the following year's World Forum at Ateneo de Manila to create the Journal of Management for Global Sustainability.

There is even a possibility that Jesuit universities and their business schools will provide very visible global leadership in transforming management education in general, and teaching and research in finance in particular, by adding a fourth tenet to Jesuit education's centuries old first three: cura personalis, homines pro aliis, and magis. The Jesuit universities and their business schools might build into their mission statements and educational actions the concept captured by the phrase "care for God's creation" as suggested by a 2014 editorial in the Journal of Management for Global Sustainability, or perhaps the phrase "tending the earth," the theme of the 2015 Loyola University of Chicago climate change conference.

The second article in this series will conclude with an invitation to contribute to the transformation of finance teaching and research which will be the basis of the third planned article. 


\section{CONCLUSION: FROM FINANCE TEACHING FOR SPECIES SUICIDE TO FINANCE TEACHING FOR SPECIES SURVIVAL AND FLOURISHING}

Business education today, with little exception, teaches, researches, and promotes a paradigm for production, consumption, and wealthdistribution that has led to the highest economic standard of living (for a portion of the world's population) ever known. However, this paradigm has had some unintended and unwanted consequences in that it has been a significant contributor-perhaps the most important contributor - to the environmental degradation and social inequities this article refers to as "global unsustainability." These negative consequences threaten the viability of the planet and the stability of society and, if permitted to continue, could threaten the continued existence of human life itself.

The current business education paradigm is based on a series of assumptions about people and the world that are widely held and rarely challenged but are now starting to be seen as deficient or simply untrue. Yet most criticisms of business education do not examine its underlying assumptions but focus rather on how to make business education more effective and efficient within the existing unsustainable paradigm.

If the business education paradigm is to change, finance teaching will have to play an important role. Current finance teaching for Business as Usual accepts that the objective of the for-profit firm is to increase its value to its "owners"; this goal, however, ignores any negative impact on the environment or society or, worse, encourages the firm to damage people and planet if it is profitable to do so. Although some finance education might recognize the need to reduce these negative impacts, actions that are typically advocated would still take place within the existing wealth maximization paradigm - a paradigm in which both Business as Usual and Amended Business as Usual are anchored. However, finance can make far greater contributions to reducing or eliminating the risks to our survival and that of other species by developing, researching, and teaching a new paradigm ("Not Business as Usual" or perhaps "Business for Global Flourishing") that is consistent with a sustainable world, one in which human beings and all living organisms prosper and thrive.

\section{REFERENCES}

Adler, P. 2015. Stewardship versus the market: A skeptical perspective. In E. Lawler, S. Mohrman, \& J. O'Toole (Eds.), Stewardship of the future. Greenleaf, expected 2015. 
Amann, W., Pirson, M., Dierksmeier, C., Von Kimakowitz, E., \& Spitzeck, H. (Eds.). 2011. Business schools under fire: Humanistic management education as the way forward. London: Palgrave Macmillan.

Bennis, W. G., \& O'Toole, J. 2005. How business schools lost their way. Harvard Business Review, 83(5): 96-104.

Bentham, J. 1776. A fragment on government. London: Payne. Available at http:// www.easternct.edu/ pauleyb/c18booktracker/node/2330 and at http://www. constitution.org/jb/frag_gov.htm (accessed November 6, 2014).

Bentham, J. 1789/1961. An introduction to the principles of morals and legislation. Garden City, NY: Doubleday.

Brogan, J. 1959. John Locke and utilitarianism. Ethics: An International Journal of Social, Political, and Legal Philosophy, 69(2): 79-93.

Business-Managed Democracy (n.d.). Standardised curricula. Available at http:// www.herinst.org/BusinessManagedDemocracy/education/curricula/index.html (accessed November 13, 2014).

Childress, S., Elmore, R., \& Grossman, A. 2006. Promoting a management revolution in public education. July 5. Boston, MA: Working Knowledge, Harvard Business School.

Coyle, D. 2001. Paradoxes of prosperity: Why the new capitalism benefits all. Cheshire, UK: Texere.

Dietz, R., \& O'Neill, D. 2013. Enough is enough: Building a sustainable economy in a world of finite resources. San Francisco: Berrett-Koehler.

Earth Values Caucus. 2005. Available at http://www.cwed.org/EVCPapertoprint_ reformat.pdf (accessed July 24, 2013).

Ehrenfeld, J. R. 2008. Sustainability by design: A subversive strategy for transforming our consumer culture. New Haven: Yale.

Ehrenfeld, J. R, \& Hoffman, A. J. 2013. Flourishing: A frank conversation about sustainability. Stanford: Stanford Business Books.

Eversole, F., Korten, D., \& Speth, J. C. (Eds.). 2014. Creating a real wealth economy: From phantom wealth to a wiser future for all humanity. Bloomington, IN: Balboa.

FAO. 2009. How to feed the world-2050: High-level expert report. New York: Food and Agriculture Organization of the United Nations. Available at http://www. fao.org/wsfs/forum2050/wsfs-background-documents/wsfs-expert-papers/en/ (accessed November 13, 2014).

Fayol, H. 1916. Administration industrielle et generale. Bulletin de la Societe de l'Industrie Minerale, fifth series, 10(3): 5-162.

Fayol, H. 1917. Administration industrielle et generale. Paris: Dunod et Pinat.

Fayol, H. 1930. Industrial and general administration (trans. J. A. Coubrough). London: Pitman.

Friedman, M. 1970. The social responsibility of business is to increase its profits. New York Times Magazine, September 13: SM17.

Fukuyama, F. 1992. The end of history and the last man. New York: Free Press. 
Gentile, M. C. 2012. Giving voice to values: How to speak your mind when you know what's right. New Haven: Yale University Press.

Gerland, P., Raftery, A. E., Ševčíková, H., Li, N., Gu, D., Spoorenberg, T., Alkema, L., Fosdick, B. K., Chunn, J., Lalic, N., Bay, G., Buettner, T., Heilig, G. K., \& Wilmoth, J. 2014. World population stabilization unlikely this century. Science, 346(6206): 234-237.

Ghoshal, S. 2005. Bad management theories are destroying good management practices. Academy of Management Learning \& Education, 4(1): 75-91.

Global Poverty Project (n.d.). 1.4 billion reasons. Available at http://www. globalpovertyproject.com/about-us/ (accessed November 13, 2014).

Gordon, R., \& Howell, J. 1959. Higher education for business. New York: Columbia University Press.

Hessen, R. 1979. In defense of the corporation. Stanford: Hoover Institution Press. Hume, D. 1738/1978. A treatise of human nature (ed. L. A. Selby-Bigge). Oxford, UK: Oxford University Press.

Hutcheson, F. 1850. Reflections upon laughter, and remarks upon the fable of the bees. London, Urie. Available at http://books.google.com/books?id=xuAtAAAA YAAJ\&printsec=frontcover\&dq=inauthor:\%22Francis+Hutcheson $\% 22 \&$ hl=en\&

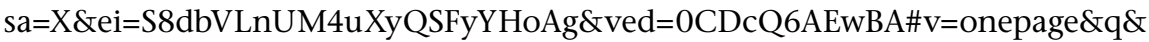
$\mathrm{f}=$ false (accessed on November 6, 2014).

IEA. 2014. World energy outlook 2014. Paris: International Energy Agency. Available at http://www.worldenergyoutlook.org/publications/weo-2014 (accessed December 15, 2014).

Jensen, M. C., \& Meckling, W. H. 1976. The theory of the firm: Managerial behavior, agency cost, and ownership structure. Journal of Financial Economics, 3(4): 305-360.

Kayes, D. C. 2002. Experiential learning and its critics: Preserving the role of experience in management learning and education. Academy of Management Learning \& Education, 1(2): 137-149.

Khurana, R. 2007. From higher aims to hired hands: The social transformation of American business schools and the unfulfilled promise of management as a profession. Princeton, NJ: Princeton University Press.

Klein, N. 2008. The shock doctrine: The rise of disaster capitalism. New York: Holt. Klein, N. 2014. This changes everything: Capitalism vs. the climate. New York: Simon \& Schuster.

Kolbert, E. 2014. The sixth extinction: An unnatural history. New York: Holt.

Korten, D. C. 1995. When corporations rule the world. San Francisco: BerrettKoehler/Kumarian.

Korten, D. C. 2010. Agenda for a new economy: From phantom wealth to real wealth. San Francisco: Berrett-Koehler.

Landsberg, B. E. 2004. The nonprofit paradox: For-profit business models in the third sector. International Journal of Not-for-Profit Law, 6(2). Available at http://www.icnl.org/research/journal/vol6iss2/special_7.htm (accessed December, 5, 2014). 
Lehmann, B. 1990. Fads, martingales, and market efficiency. Quarterly Journal of Economics, CV(1): 1-28.

Leonard, A. 2011. The story of stuff: The impact of overconsumption on the planet, our communities, and our health-and how we can make it better. New York:

Free Press.

Locke, J. 1690a/1975. An essay concerning human understanding. New York: Oxford

University Press.

Locke, J. 1690b/1980. Second treatise on government. New York: Hackett Publishing. Lynas, M. 2008. Six degrees: Our future on a hotter planet. Washington, DC:

National Geographic Society.

Lynn, L. 2006. Public management: Old and new. New York: Routledge.

Marks, S. 1997. The end of history? Reflections on some international legal theses.

European Journal of International Law, 8: 449-476.

McKibben, B. 1989. The end of nature. New York: Anchor/Random House.

McKibben, B. 2010. Earth: Making a life on a tough new planet. New York: Times Books.

McLaughlin, H., \& Thorpe, R. 1993. Action learning-a paradigm in emergence: The problems facing a challenge in traditional management education and development. British Journal of Management, 4(1): 19-27.

Mill, J. S. 1861/1998. Utilitarianism. New York: Oxford University Press.

Mintzberg, H. 2004. Managers not MBAs: A hard look at the soft practice of managing and management development. San Francisco: Berrett-Koehler.

Nixon, R. 2011. Slow violence and the environmentalism of the poor. Cambridge, MA: Harvard.

Nunno, J., \& Nunno, R. 2010. Top 10 greatest benefits of capitalism. Available at http://listverse.com/2010/12/24/top-10-greatest-benefits-of-capitalism/ (accessed November 6, 2014).

Ollman, B. 1999. Market economy: Advantages and disadvantages. https://www.nyu. edu/projects/ollman/docs/china_speech2.php (accessed November 6, 2014).

Parekh, S. G., \& Singh, B. 2007. An MBA: The utility and effect on physicians' careers. Journal of Bone and Joint Surgery, 89(2): 442-447.

Pfeffer, J., \& Fong, C. 2002. The end of business schools? Less success than meets the eye. Academy of Management Learning \& Education, 1(1): 78-95.

Pfeffer, J., \& Fong, C. 2004. But can you teach it? The Economist, May 20. Available at http://www.economist.com/node/2685892 (accessed October 9, 2014).

Pierson, F. C. 1959. The education of American businessmen: A study of universitycollege programs in business administration. New York: McGraw-Hill.

Piketty, T. 2014. Capital in the twenty-first century (trans. A. Goldhammer). Cambridge, MA: Belknap/Harvard University Press.

Porter, L. W., \& McKibben, L. E. 1988. Management education and development: Drift or thrust into the 21st century? New York: McGraw-Hill.

Posner, R. A. 2009. A failure of capitalism: The crisis of '08 and the descent into depression. Boston: Harvard University Press.

Rand, A. 1966. Capitalism: The unknown ideal. New York: New American Library. 
Reno, R. R. 2013. The triumph of capitalism. Available at http://www.firstthings. com/onthesquare/2013/04/the-triumph-of-capitalism (accessed July 24, 2013).

Rosenberg, B., Reid, K., \& Lanstein, R. 1985. Persuasive evidence of market inefficiency. The Journal of Portfolio Management, 11(3): 9-16.

Ryan, L. 2012. Top 10 disadvantages of capitalism. Available at http:// listverse.com/2012/01/16/top-10-disadvantages-to-capitalism/ (accessed November 6, 2014).

Salls, M. 2004. It's back to business-basics for nonprofits. February 23. Boston, MA: Working Knowledge, Harvard Business School.

Sarkar, S. 2012. The crisis of capitalism: A different study of political economy. Berkeley: Counterpoint.

Saucedo, J. M., \& Puri, L. 2011. Residency training programs need to add business education. August. American Academy of Orthopedic Surgeons Now, Rosemont, IL.

Schlanger, Z. 2014. Pentagon report: U.S. military considers climate change a "threat multiplier" that could exacerbate terrorism. Newsweek, October 14. Available at http://www.newsweek.com/pentagon-report-us-military-considers-climatechange-immediate-threat-could-foster-277155 (accessed November 7, 2014).

Schor, J. N. 2010. Plenitude: The new economics of true wealth. New York: Penguin. Seldon, A. 2004. The virtues of capitalism: The collected works of Arthur Seldon, vol. 1 (ed. C. Robinson). Indianapolis, IN: Liberty Fund.

Shah, A. 2013. Poverty facts and stats. Global Issues, January 7. Available at http://www.globalissues.org/article/26/poverty-facts-and-stats (accessed December 6, 2014).

Shalowitz, J. I., Nutter, D. O., \& Snarr, J. F. 1996. Medicine and management: A combined educational program. Journal of Health Administration Education, 14(3): 305-313.

Social Justice Secretariat at the General Curia of the Society of Jesus. 2011. Healing a broken world. Rome: Society of Jesus.

Spitzeck, H., \& Pirson, M. (Eds.). 2009. Humanism in business. London: Palgrave Macmillan.

Starik, M., Rands, G. P., Marcus, A. A., \& Clark, T. S. (Eds.). 2010. In search of sustainability in management education. Academy of Management Learning \& Education (Special Issue: Sustainability in Management Education), 9(3): 377-383.

Stead, J., \& Stead, E. 2009. Management for a small planet (3rd ed.). Armonk, NY: Sharpe.

Stearns, P. 2006. Consumerism in world history: The global transformation of desire. New York: Routledge.

Stiglitz, J. 2013. The price of inequality: How today's divided society endangers our future. New York: Norton.

Stoner, J. A. F. 1982. Management. Englewood Cliffs, NJ: Prentice-Hall.

Stout, L. 2012. The shareholder value myth: How putting shareholders first harms investors, corporations, and the public. San Francisco: Berrett-Koehler. 
Thomas, C. D., Cameron, A., Green, R. E., Bakkenes, M., Beaumont, L. J., Collingham, Y. C., Erasmus, B. F. N., Ferreira de Siqueira, M., Grainger, A., Hannah, L., Hughes, L., Huntley, B., Van Jaarsveld, A. S., Midgley, G. F., Miles, L., Ortega-Huerta, M. A., Peterson, A. T., Phillips, O. L., \& Williams, S. E. 2004. Extinction risk from climate change. Nature, 427(6970): 145-148.

Thomas, H., Lee, M., Thomas, L., \& Wilson, A. 2012. Promises fulfilled and unfulfilled in management education. Bingley, UK: Emerald.

Thomas, H., Lee, M., Thomas, L., \& Wilson, A. 2014. Securing the future of management education: Competitive destruction or constructive innovation? Bingley, UK: Emerald.

UN. 2013. World population prospects-the 2012 revision, volume I: Comprehensive tables 2013, xviii. New York: United Nations. Available at: http://esa.un.org/ wpp/Documentation/pdf/WPP2012_Volume-I_Comprehensive-Tables.pdf (accessed November 14, 2014).

UNDP. 2014. United Nations Development Programme: The millennium development goals report 2014. New York: United Nations. Available at: http:// www.undp.org/content/undp/en/home/librarypage/mdg/the-millenniumdevelopment-goals-report-2014.html (accessed July 13, 2014).

US Department of Defense. 2014. 2014 climate change adaptation roadmap. Washington, DC: US Department of Defense. Available at http://www.acq.osd. mil/ie/download/CCARprint.pdf (accessed November 7, 2014).

Viralnova. 2014. Scientists have pinpointed when the human race will go extinct. Spoiler alert: It's soon. Available at http://www.viralnova.com/human-raceextinction/ (accessed November 7, 2014).

Wankel, C., \& Stoner, J. A. F. (Eds.). 2009. Management education for global sustainability. Charlotte, NC: IAP.

Werner, F. M., \& Stoner, J. A. F. 2014. Collaboration among Jesuit business schools: Transforming finance teaching to contribute to a more sustainable world. July 21. Presentation at the 20th World Forum of the International Association of Jesuit Business Schools, Seoul, Republic of Korea.

Wilson Center. 2011. Ten billion: UN updates population projections, assumptions on peak growth shattered. Available at http://www.newsecuritybeat.org/2011/05/ ten-billion-un-updates-population-projections/ (accessed November 13, 2014).

Wilson, R. 2013. Rethinking public administration: The case for management. Minneapolis, MN: Mill City Press.

World Bank (n.d.). The state of the poor: Where are the poor and where are they poorest? Available at http://www.worldbank.org/content/dam/Worldbank/ document/State_of_the_poor_paper_April17.pdf (accessed November 13, 2014).

Young, D. R. 2002. The influence of business on nonprofit organizations and the complexity of nonprofit accountability looking inside as well as outside. The American Review of Public Administration, 32(1): 3-19. 